\title{
Mitral valve replacement with small cavity of left ventricle
}

\author{
V Popov ${ }^{*}$, V Lazoryshinets, V Shimon, Yu Lukach \\ From 23rd World Congress of the World Society of Cardio-Thoracic Surgeons \\ Split, Croatia. 12-15 September 2013
}

\section{Background}

To determine significance of patient-prosthesis mismatch (PPM) (indexed effective orifice area $<1,2 \mathrm{~cm}^{2} / \mathrm{m}^{2}$ ) after isolated mitral valve replacement(MVR) in pts with small cavity of left ventricle (SCLV) (end-diastolic volume $(\mathrm{EDV}) \leq 75 \mathrm{ml})$ during hospital period.

\section{Materials}

1811 adult patients (pts) with isolated mitral valve disease MVR were operated in Institute from 01.01.2000 till 01.01.2007. There were 127 (7,0\%) pts with SCLV. Among them $48(37,8 \%)$ males and $79(62,2 \%)$ females in average age $53,2+7,1$ yy. $110(86,6 \%)$ pts belonged to IV NYHA class of heart failure, $17(13,4 \%)$ - to III. Previous closed mitral comissurotomy was performed in $31(24,4 \%)$ pts, to 7 pts - twice (closed recomissirothomy). Average body surface area (BSA) was $1,87 \pm 0,32 \mathrm{~m}^{2}$. Following prostheses were implanted: bileaflet (Saint Jude, Carbomedics, On-X, Edwards-Mira) $(\mathrm{n}=88)$ and monodisc as Alcarbon`s type (MIKS, LIKS) $(\mathrm{n}=40)$. Following prosthesis sizes were used: $23 \mathrm{~mm}(\mathrm{n}=1), 25 \mathrm{~mm}(\mathrm{n}=74), 26 \mathrm{~mm}(\mathrm{n}=3)$, $27 \mathrm{~mm}(\mathrm{n}=49)$.

\section{Results}

Hospital mortality $(\mathrm{HM})$ was $5,5 \%(\mathrm{n}=7)$. It was higher in cases with $27 \mathrm{~mm}$ size of implanted prosthesis - 8,2\% $(\mathrm{n}=4 / 49)$ than in other group $-3,8 \%(\mathrm{n}=3 / 78)$ $(\mathrm{p}<0,01)$. PPM were marked in $21(16,5 \%)$ pts with BSA $>1,75 \mathrm{~m}^{2}$ and size of prothesis $25 \mathrm{~mm}$ but there were no influence on HM. Heart failure and PPM were marked in $5(3,9 \%)$ pts with BSA $>1,75 \mathrm{~m}^{2}$, size of prothesis $25 \mathrm{~mm}$ and cavity of LV (EDV $\leq 50 \mathrm{ml})$. Riskfactors for PPM in SCLV group of pts on hospital stage were: small cavity of $\mathrm{LV}(\mathrm{EDV} \leq 50 \mathrm{ml})$ especially in pts

\footnotetext{
* Correspondence: vladpopov@ukr.net

Department of Acquired Heart Diseases, Natonal Amosov's Institute of Cardiovascular Surgery, Kyiv, Ukraine
}

(c) 2013 Popov et al; licensee BioMed Central Ltd. This is an Open Access article distributed under the terms of the Creative Commons Attribution License (http://creativecommons.org/licenses/by/2.0), which permits unrestricted use, distribution, and reproduction in any medium, provided the original work is properly cited.
Cite this article as: Popov et al:: Mitral valve replacement with small cavity of left ventricle. Journal of Cardiothoracic Surgery 2013 8(Suppl 1): O288. hypertension, mitral valve calcification $3+$, duration of rheumatic disease $\geq 25$ years.

\section{Conclusion}

Pts with SCLV are in group of higher risk for operation and increasing risk of PPM. In these cases implantation of $25 \mathrm{~mm}$ prosthesis is expedient, but for pts with EDV $50 \mathrm{ml}$ and BSA $>1,75 \mathrm{~m}^{2}$ it may lead for significant PPM and heart failure. $23 \mathrm{~mm}$ prosthesis may use in pts with body mass $\leq 45 \mathrm{~kg}\left(\mathrm{BSA}<1,5 \mathrm{~m}^{2}\right)$.

Published: 11 September 2013

Submit your next manuscript to BioMed Central and take full advantage of:

- Convenient online submission

- Thorough peer review

- No space constraints or color figure charges

- Immediate publication on acceptance

- Inclusion in PubMed, CAS, Scopus and Google Scholar

- Research which is freely available for redistribution 